\title{
Histopathological Study of Bone Tumors
}

\author{
Dr. Shubhi Sharma, Dr. Nandita P. Mehta
}

Ahmedabad, Gujarat, India

\begin{abstract}
Objective: To determine the spectrum of various bone tumors and their relative frequency at tertiary care centre civil hospital Ahmedabad. Material and methodology: A retrospective review of histopathological reports of all bone specimens received in the Department of Pathology (histopathology section), civil hospital Ahmedabad hospital for a period of 2 years from January 2014 -December 2015 was done. Result: On histopathological diagnosis, amongst neoplastic lesions incidence of benign tumors was 79 cases $(72 \%)$ and malignant tumors was 31 cases $(28 \%)$. Among the benign tumors, the most common benign tumor was Giant cell tumor (22\%) followed by osteochondroma(20\%). Osteosarcoma was commonest malignant tumor 38.6\%. Maximum number of bone tumors occurred in 25-50 years of age and the male to female ratio was 1.2:1. Conclusions: Bone tumors occurred predominantly within 25-50 years of age with a male preponderance. Osteochondroma and giant cell tumor was the most common benign tumor and Osteosarcoma was the most common malignant bone tumour. Knee joint is the most common site for bone tumors.
\end{abstract}

Keywords: Bone tumours, Histopathology, Giant cell tumour, Osteochondroma, Osteosarcoma

\section{Introduction}

In the WHO classification, most bone neoplasms are classified as either benign or malignant. Although a sharp distinction between these two categories is feasible in most of them, some neoplasm exhibit borderline and intermediate characterstics. ${ }^{4}$ Bone tumors are diverse in their clinical and morphological feature and range in behavior from innocuous to rapidly fatal. Accurate diagnosis, proper staging and appropriate treatment are thus necessary to ensure maximum patient survival and maintain optimal function of an affected body part. $^{2}$

Histopathological study enables us to understand the spectrum of bone lesion and give an idea of different bone tumors in population and different age groups and sex. A bone tumor often poses a diagnostic challenge to surgical pathologist. An integrated approach involving radiographic, histologic and clinical data are necessary to form an accurate diagnosis to determine the degree of activity and malignancy of each lesion. ${ }^{3}$

\section{Aims and Objectives}

To study spectrum of various bone tumors and correlate them with age, site and type of lesions.

\section{Materials \& Methods}

The study was carried out at our tertiary care centre from January 2014 to December 2015 (2 years). Total 110 cases were selected and in all patients bone lesions were diagnosed radiologically. In orthopedic OPD, patients clinically presented with pain, swelling, non healing fracture. Detailed history was taken which mainly included age, sex, place of residence, occupation, fever, weight loss, cough, haemoptysis or history suggestive of systemic involvement. All patients were subjected to through physical examination both, systemic and general examination. In all patient radiological and routine investigation were done. Biopsy for histopathology was performed in all patients for the diagnosis of lesions. In selected cases IHC was performed to confirm histopathological findings.

\section{Result}

A total of 110 cases of primary bone tumors were identified in the period of January 2014 to December 2015. Amongst neoplastic lesions incidence of benign tumors was 79 cases $(72 \%)$ and malignant tumors was 31 cases $(28 \%)$.

Table 1: Showing proportion of different bone tumors.

\begin{tabular}{|l|l|}
\hline Osteoclastoma (Giant cell tumor )-17 & Osteosarcoma-12 \\
\hline Osteochondroma(Exostosis)-15 & Chondrosarcoma-6 \\
\hline Fibrous dysplasia-13 & Synovial sarcoma-5 \\
\hline Ossifying Fibroma-10 & Metastasis-2 \\
\hline Osteoma-11 & Chordoma-1 \\
\hline Chondroma-6 & Ewing's sarcoma-5 \\
\hline Aneurysmal bone cyst-7 & \\
\hline Total Benign lesions-79 & Total malignant lesions-31 \\
\hline
\end{tabular}


International Journal of Science and Research (IJSR)

ISSN (Online): 2319-7064

Index Copernicus Value (2013): 6.14 | Impact Factor (2014): 5.611

Table 2: Gender distribution of the lesions of bone

\begin{tabular}{|l|c|c|c|}
\hline Male & 40 & 19 & 59 \\
\hline Female & 39 & 12 & 51 \\
\hline Total & 79 & 31 & 110 \\
\hline
\end{tabular}

Out of 110 patients, $59(53.7 \%)$ were male and 51(46.3\%) were female. Male female ratio is 1.2:1

Table 3: Gender distribution of benign lesions

\begin{tabular}{|l|c|c|c|}
\hline Osteoclastoma (Giant cell tumor )-17 & 7 & 10 & 17 \\
\hline Osteochondroma (Exostosis)-15 & 8 & 7 & 15 \\
\hline Fibrous dysplasia-13 & 8 & 5 & 10 \\
\hline Ossifying Fibroma-10 & 3 & 4 & 11 \\
\hline Osteoma-11 & 7 & 2 & 6 \\
\hline Chondroma-6 & 4 & 2 & 7 \\
\hline Aneurysmal bone cyst-7 & 5 & $39(49.3 \%)$ & $79(100 \%)$ \\
\hline Total Benign lesions-79 & $40(50.6 \%)$ & 7 & \\
\hline
\end{tabular}

Table 4: Gender distribution of malignant lesions

\begin{tabular}{|l|c|c|c|}
\hline Osteosarcoma-12 & 8 & 4 & 12 \\
\hline Chondrosarcoma-6 & 5 & 1 & 6 \\
\hline Synovial sarcoma-5 & 1 & 4 & 5 \\
\hline Metastasis-2 & 2 & 0 & 2 \\
\hline Chordoma-1 & 0 & 1 & 1 \\
\hline Ewing's sarcoma-5 & 3 & 2 & 5 \\
\hline & $19(61.2 \%)$ & $12(38.7 \%)$ & $31(100 \%)$ \\
\hline
\end{tabular}

Table 5: Age wise distribution of the bone lesions

\begin{tabular}{|c|c|c|c|}
\hline & BENIGN & MALIGNANT & \\
\hline$<25$ & 37 & 7 & $\mathbf{6 1}$ \\
\hline $\mathbf{2 5 - 5 0}$ & 37 & 0 & 5 \\
\hline$>50$ & 5 & 31 & 110 \\
\hline TOTAL & 79 & 24 & \\
\hline
\end{tabular}

61 cases $(55 \%)$ were found between $25-50$ years \& 44

cases $(40 \%)$ were found in $<25$ years age group 


\section{International Journal of Science and Research (IJSR)}

ISSN (Online): 2319-7064

Index Copernicus Value (2013): 6.14 | Impact Factor (2014): 5.611

Table 6: Site distribution of three most common bone tumors

\begin{tabular}{|l|l|}
\hline & Femur-9 \\
Osteoclastoma (Giant cell tumor)-17 & Tibia- 5 \\
& Humerus-2 \\
& Ulna-1 \\
& Femur-3 \\
Osteochondroma (Exostosis)-15 & Tibia-7 \\
& Calcaneum-2 \\
& Humerus-1 \\
& Rib-1 \\
\hline & Scapula-1 \\
Osteosarcoma-12 & Femur-8 \\
& Ulna- 3 \\
\hline
\end{tabular}

Most common site of the three commonest tumors is around the knee joint i.e. on femur and tibia. Other less common sites are ulna, calcaneum, rib scapula etc.

\section{Discussion}

In this study, out of the 110 bone specimens received during the study period benign lesions were found to be more common than malignant lesions. Most tumors of the bone showed male preponderance with male to female ratio of 1.2:1. Similar findings were reported in other studies.

Table 7: Comparison of our study with other studies

\begin{tabular}{|l|c|c|c|}
\hline & Our study & Nigeria ${ }^{l}$ & 205 \\
\hline Total no. Of cases & 110 & 77 & $111(51.3 \%)$ \\
\hline Males & $59(53.6 \%)$ & $51(66.2 \%)$ & $94(48.7 \%)$ \\
\hline Females & $51(46.4 \%)$ & $26(33.8 \%)$ & $131(63.90 \%)$ \\
\hline Benign & $79(72 \%)$ & $61(79.2 \%)$ & $74(36 \%)$ \\
\hline Malignant & $31(28 \%)$ & $16(20.8 \%)$ & $22(11.1 \%)$ \\
\hline Gaint cell tumor & $17(15 \%)$ & $18(23.5 \%)$ & $45(21.95 \%)$ \\
\hline Osteochondroma & $15(13 \%)$ & $34(44.1 \%)$ & $45(21.95 \%)$ \\
\hline Osteosarcoma & $12(38.6 \%)$ & $7(9.1 \%)$ & \\
\hline
\end{tabular}

Both our study and other studies show male predominance in bone tumors. Benign tumors are more than malignant tumors both in our study and other studies. In our study giant cell tumor is the most common benign tumor followed by osteochondroma while in other studies osteochondroma is the most common benign tumor followed by giant cell tumor. Both our study and other studies show osteosarcoma as the most common malignant tumor of bone. The peak age incidence of primary bone tumors in our study was seen between 25 to 50 years. Metastatic bone tumors were seen in older age group (above 50 years). Most common site of involvement of three commonest tumors is around the knee joint.

\section{References}

[1] F.B. Abdulkareem et al, Pathological study of Bone Tumors at National Orthopedic Hospital, Lagos Nigeria, West African Journal of Medicine.

[2] Lateef Ahmed Wani et al, Primary bone Tumor in Kashmir Valley, A Retrospective Histopathological Study, International Journal of Basic And Applied science.

[3] Negash BE, Admasie D, Wamisho BL, Tinsay MW, bone Tumors at Addis Abbas University Ethiopia, Agreement Between Radiological and Histopathological Diagnosis - A 5 year analysis at Black Lion Teaching Hospital, Malawi Med J 1:62-5.

[4] Rosai and Ackerman's Surgical Pathology, Tenth edition 